\title{
INTEGRATED METHODS FOR THE CONSERVATION AND RESTORATION OF ARCHAEOLOGICAL SITES. AN EXPERIMENTAL APPLICATION ON THE "BALNEUM" OF PIAZZA DANTE IN CATANIA (ITALY)
}

\author{
G. Sanfilippo ${ }^{1 *}$, A. Mondello ${ }^{1}$, F. M. La Russa ${ }^{1}$, L. La Rosa ${ }^{2}$ \\ ${ }^{1}$ Department of Civil Engineering and Architecture, University of Catania, via Santa Sofia 64, 95123, Catania, Italy \\ ${ }^{2}$ Building Engineer and Architect, Catania, Italy \\ giulia.sanfilippo@darc.unict.it, attilio.mondello@darc.unict.it, federico.larussa@phd.unict.it, lauralarosa3@gmail.com
}

KEY WORDS: Archaeological restoration, Conservation, Photogrammetry, Digital survey, Digital replica, Roman ruins.

\begin{abstract}
Archaeological sites in urban areas are often poorly integrated with the modern urban fabric and appear as "trenches" at a lower level than the road. They become neglected and unvalued places. The study of archaeological ruins in urban centres must involve archaeologists and architects to integrate restoration, enhancement and improvement of physical and visual accessibility projects. New digital technologies can improve these activities thanks to 3D models, "digital replicas" that allow even remote study (especially during a pandemic). The paper presents the case study of a private Roman-imperial bath in Catania. The open-air site is located at a depth of 3 metres above the road level and is not exploited. Our study consisted of historical-bibliographical research, direct and SfM surveys that allowed creating a high-resolution textured 3D model. We have extracted orthophotos and sections for geometric and technical-constructive analyses and recognition of decay from this model. We drew up an archaeological restoration and valorisation design. In addition, we imported the model into the Sketchfab portal. So, we enriched the mesh with information from the analyses employing specific tags about annotations, 2D drawings, historical and technical-scientific information. In this way, the model becomes an interactive document to monitor over time the conservation state, validate the restoration design and contribute to the valorisation of the site. This is an easy tool of exchange between all involved users (researchers, professions and students). Thus, the digital replica also represents a very high potential for dissemination purposes.
\end{abstract}

\section{INTRODUCTION}

Archaeological ruins in urban areas are often found accidentally due to road works that uncover relevant historical layers. However, the excavation can be a trench unrelated to the modern urban fabric. If not well integrated with the context, these sites soon become forgotten and neglected areas. In these cases, valorisation and archaeological restoration works are needed by an interdisciplinary team. The architect role is essential to set up the site, perform graphic and topographical surveys, cognitive analysis of materials, construction techniques and conservation state, and then find restoration design solutions (Romeo, 2014). In the early analysis stages, the impervious nature of an archaeological site does not facilitate these operations because it is often located lower than street level. The research group is studying a small Roman archaeological site within the baroque historical centre of Catania to carry out the cognitive analysis and the restoration project (La Rosa, 2020). Moreover, thanks to the help of an SfM model, we developed a "digital replica" that can be exploited for restoration site and valorisation.

\section{STATE OF THE ART}

\subsection{Digital techniques for architectural and archaeological} restoration

In the restoration field, several studies have shown how SFM survey allows rapid and detailed geometric and technicalconstructive knowledge (Acierno, 2020; D'Agostino et al., 2018), especially in dangerous conditions or difficult accessibility due to seismic events (Bartolomucci and Trizio, 2015; Mirabella Roberti, 2018). These non-invasive technologies offer good support for a "conscious fruition" of the cultural heritage by researchers and restorers; this is especially so when the virtual model investigates specific conservation issues and is not a purely formal exercise (Fiorani and Balletti, 2017). Models with meshes or TLS point clouds have already been tested for masonry stratigraphic analysis and related decays in archaeological sites or historic buildings. Examples are the use of structured light lasers to detect morphological characters and efflorescence colouration of Roman masonry in opus reticolatum of the 2 nd century $\mathrm{AD}$ in Rome (Dal Mas, 2017) or the combined use of photogrammetric and laser scanner surveys to define volume and surfaces of an eroded 18th-century calcarenite balustrade in Catania (Sanfilippo et al., 2015).

There are also many cases of SfM models for the definition of documentation project, geometric analysis, data archiving and dissemination (Valle Melón et al., 2016).

Thanks to the data information about geometry and preservation, the models represent the monuments' real "digital replicas". The "digital replica" has been well defined by a recent study that analysed a Roman archaeological site in Romania (Demetrescu et al., 2020). The digital replica is not the exact copy of the studied object because the digitization operates a discretization of the data, choosing only some geometric, mechanical, physical, chromatic characteristics. The replica is not a virtual reconstruction, which instead indicates the hypothetical reconstruction (from historical data) of a lost cultural asset. The cited study points out that the digital replica 
is a visually credible copy of an archaeological site surveyed by qualified architects and archaeologists, which offers the possibility to "experience" the real object and allows to the users scientific "autoptical" analysis (such as a masonry stratigraphic reading) (Demetrescu et al., 2020). However, restorers warn against possible automatisms that could favour material substitutions and limit the possibility of using replicas to a limited range of possibilities well justified from a conservation perspective (Fiorani and Balletti, 2017). A replica of restoration aid (not in substitution of the archaeological find) is the study of the 3D model of the remains of the windows of the Paleochristian Basilica of St. Sabina in Rome. The replica has been helpful to model compatible exhibition stands in PET foam (Iaccarino et al., 2017).

\subsection{Digital replicas of cultural heritage for collaborative studies based on 3D web portals}

Recent studies have integrated technical information about restoration design into digital replicas. They have also attributed an educational role to restoration that helps to better understand the materiality of the cultural heritage (Quattrini, 2019). This is also opening up the restoration field to the "digital humanities" new frontiers, with their opportunities and issues. Web portals, such as Europeana or Sketchfab, are taking an increasingly central role in the dissemination of these digital models obtained from surveying operations (Barrettara, 2013; Guidi et al., 2013). In this context, it is worth it to mention the AIOLI reality-based 3D annotation platform. This cloud-based platform allows users, related to the worldwide Cultural Heritage community, to build semantically enriched 3D descriptions of cultural heritage through photogrammetric models and 3D annotations linked with additional resources (Pamart et al., 2019). Due to the global pandemic, these technologies become useful academic teaching tools in absence of on-site experience (Pollalis et al., 2018). The use of 3D web portals such as Sketchfab does not stop at dissemination and education but becomes a low-cost tool for remote collaboration ("Sketchfab for Teams") during the study of the site itself. (Denoyel, 2020) Indeed, this 3D model viewer web-based allow different type of actions (zooming in and out, walk around the model, wireframe and textured views of the model, measuring and analysing sections of the model, etc.) which enable the user to study and investigate the model in many different ways (Champion et al., 2020).

\section{METHODOLOGY}

After historical and bibliographic research on the archaeological site and the urban area, we carried out a Structure from Motion (SfM) photogrammetric survey of the Balneum of Piazza Dante in Catania. Due to the limited accessibility of the archaeological site, this technique helped to obtain an accurate digital model, taking high-resolution photos from the site perimeter and implementing direct measurements. Since the site is in an urban area under the ground level, we needed to carefully plan in advance what time to carry out the acquisition phase of the survey to avoid sudden change of lightness. Afterwards, an image-processing phase was necessary for optimizing image characteristics like brightness and contrast to maximize the final texture quality and facilitate the automatic alignment phase, which led to point-cloud and mesh geometric models. The information was compared to detailed metric data provided by the literature and new direct surveys. The digital model allowed the restitution of processed data such as sections and orthophotos. We have analysed the stratigraphic units of the walls, identifying the building materials, the type of masonry and any discontinuities that indicate different construction phases and/or phenomena of decay. The high-resolution textured model has also allowed us to recognize the degradations, to highlight promptly and effectively the pathologies. The detected decays were classified according to the most recurrent categories in an archaeological site: uncontrolled plant soil, loss of verticality and alignment of walls, water infiltration on the head of the walls, weedy vegetation (Marino, 2019). Thus, we were able to draw up a restoration design of the archaeological ruin (in terms of materials and masonry structures) and an enhancement and fruition plan of the area, also considering accessibility criteria for people with disabilities (Sanfilippo et al., 2021). Besides having used the photogrammetric model for the geometric analysis, the construction techniques and the state of conservation, this "digital replica" has become a experimental database that we have enriched with all the information produced during the analysis phase (images, descriptions, data, etc.). We designed the virtual working environment not only like a simple digital repository for storing and exchanging technical 2D drawings and documents. We have selected relevant points of the site in the textured model to insert tags, annotations and links for the direct exchange of information and drawings. Thanks to the $3 \mathrm{D}$ representation, it is possible immediately to contextualise the documentation collected and under processing. To accomplish this goal, we had to optimize the photogrammetric model to achieve the best possible balance between mesh density, texture resolution and final model file size.

\section{THE “BALNEUM" OF PIAZZA DANTE}

\subsection{The thermal baths of a late imperial domus}

The archaeological site called Balneum is in the historical centre of Catania (Fig. 1), in Montevergine hill, in the current Piazza Dante, near the monumental Benedictine Monastery of San Nicolò l'Arena (now Department of Humanities of the University of Catania). Here there was the Acropolis of the Greek city and, in the Roman imperial age, the residential area with patrician Domus, important public buildings and thermal baths. (Branciforti, 2010). The archaeological excavation was carried out in 1958. However, already in 1700, historians and archaeologists reported significant findings related to thermal baths under the square, the Monastery and other monumental complexes nearby (Fig. 2). Thanks to the former Monastery restoration works in 1982, it was clarified that, in the imperial age, the area was an elegant residential district (Branciforti, 2010). The Balneum is a small private bath from the late imperial age, probably located in the peristyle garden of a Domus adjacent to the current monastery walls (Wilson, 1990).

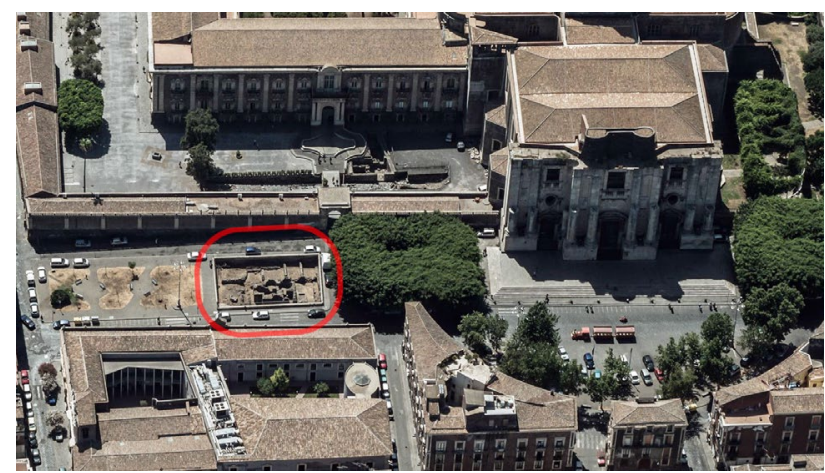

Figure 1. The archaeological site of Balneum in Piazza Dante within the Catania historical center. 
Despite several historical and archaeological studies, the real extension of the Domus and the diachronic evolution of the existing walls are not known. Only the shape of the rooms and the observation of the wall textures made it possible to hypothesise the functional distribution of the rooms; thus, the living rooms, baths, the water channelling system, the hypocaust openings and the ancient peristyle area were identified (Marletta, 2010). The site is now part of the Archaeological and Landscape Park of Catania and the Aci Valley. Today the excavation is in a reasonably fair state of conservation but not well exploited; it is enclosed in a rectangular "trench" measuring $23.50 \times 15.00$ meters and 3.00 meters deep. The site is bordered by a retaining reinforced concrete wall and protected by a metal railing that does not allow either physical or visual access.

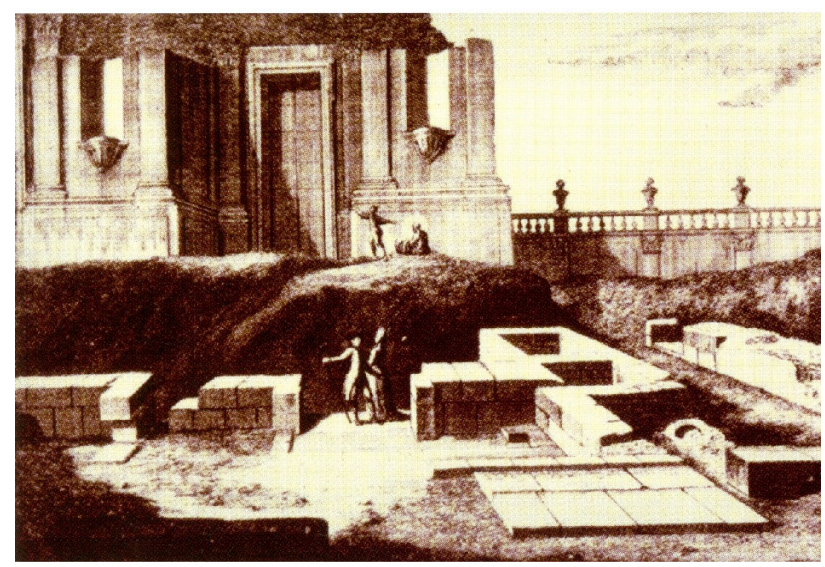

Figure 2. Archaeological excavations in Piazza Dante in the 18th century: engraving by A. Zacco from a drawing by L.

Mayer, ca. 1780 (Pagnano, 2007).

\subsection{Digital survey and digital model optimization for Sketchfab uploading and dissemination}

In the past, the archaeological site survey was carried out only with traditional methods during the various excavation phases. Subsequently, archaeologists identified the functions of the rooms and hypothesised the construction phases of the Domus (Giudice et al., 1979; Marletta, 2010). We implemented the metric and technical-constructive information and conducted an initial survey of the manifestations of degradation with a digital model. The workflow of the digitisation of the site included different phases: acquisition of the photos, processing of the dense cloud, creation of the mesh model $(1,276,316$ triangles) and texturing the mesh model.

The acquisition phase was conducted using the digital reflex camera CANON 77D with a 24.2 megapixels CMOS sensor and a standard zoom lens 18 - $55 \mathrm{~mm}$ EF-S f/3.5-5.6. From a preliminary analysis of the site, it was decided to conduct the acquisition phase during the afternoon to avoid areas affected by direct sunlight. In order to avoid the use of tripods (difficult to use on the sloping perimeter of the site), the shutter speed was set to $1 / 125$ seconds to prevent image blurring. In addition, we set a lens aperture of f1 8 to ensure good focus in the images. Higher values would have required an increase in ISO sensitivity, resulting in higher levels of noise in the images. The previous settings and diffuse light conditions allowed a maximum ISO sensitivity of 1600 . Images were taken with a focal length of $18 \mathrm{~mm}$ in portrait format and distance between shooting points was approximately 1 metre. A total of 258 photos (with a size of $4000 \times 6000$ pixels in '.RAW' image format) were taken in about 35 minutes. Before processing the image dataset, we improved some image characteristics using Adobe Lightroom to optimise the alignment phase and improve the final texture quality. shadows were lightened, contrast and sharpness increased. The photographic dataset was processed using Agisoft Metashape. The photogrammetric reconstruction process was made using an Asus Rog Strix laptop with an Intel Core i7 7700HQ $(2.80 \mathrm{GHz})$ as CPU, an NVIDIA GeForce GTX $1060(6 \mathrm{~Gb})$ as GPU and $16 \mathrm{~Gb}$ of RAM. First, we set up the alignment process with the level 'high' of accuracy, no tie point limit and 40,000 as regards the key point limit. All images were correctly aligned (in 6 minutes and 23 seconds) and we obtained a sparse cloud of 623,772 points. Then, we proceeded to reconstruct the dense cloud. Since our purpose was to create a model light enough to upload to a 3D web portal, we set the dense cloud reconstruction quality to 'Medium'. In addition, given the size of the site, we chose the 'Aggressive' filter to make it easier to clean up the residual noise in the point cloud. Finally, we obtained a dense cloud of $6,381,584$ points (in 18 minutes and 5 seconds). Thanks to on-site measures regarding specific points, we were able to scale the model using Metashape markers. Afterwards, the mesh model was created with the 'High' level of face counts which is equal to $1,276,316$ faces. This process took 6 minutes and 19 seconds (Tab. 1). Regarding the texturization of the polygonal model, after several attempts we managed to achieve a satisfactory result by setting the creation of 6 textures of 4096 pixels (in 6 minutes and 45 seconds). The entire process, acquisition phase to the mesh textured model, took about 1 hour and 12 minutes.

\begin{tabular}{|l|c|}
\hline SFM Survey metrics & Quantities \\
\hline & \\
Camera & Canon EOS 77D \\
Image resolution & $6000 \times 4000$ pixel \\
Image number & 258 \\
Time of acquisition & 35 minutes \\
Sparse Cloud points & 623,772 \\
Dense Cloud points & $6,381,584$ \\
Mesh faces & $1,276,316$ \\
Time of processing & 37 minutes \\
\hline
\end{tabular}

Table 1. SFM Survey metrics

The obtained model (Fig. 3) has been used to carry out all the cognitive analyses about the geometric, technical, and constructive characteristics and identify the decay.

Through the online platform Sketchfab, the model obtained was uploaded online to be used for research as well as for educational and dissemination purposes. For this reason, it was necessary to optimise the size of the model file. So, we decided to reduce the number of faces by about $30 \%$ (from $1,276,316$ to $871,145)$ while maintaining the quality of the texture.

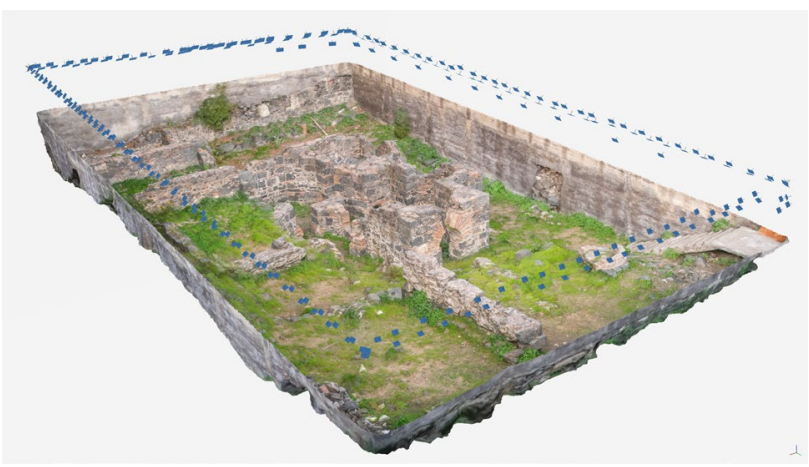

Figure 3. Dataset and model obtained with the SFM method. 


\subsection{Formal and constructive aspects}

The archaeological site (Fig. 4) consists of three rectangular rooms corresponding to the living rooms of the Domus and the bath complex in the centre of the presumed garden of the house. The Balneum consists of four rooms of different shapes (a square, an octagon, a circle and a bi-apsidal quadrilateral) and an external rectangular pool (Fig. 5). The four rooms were heated, as can be seen from the openings at the level of the hypocaust; for this reason, these have been classified as tepidarium, calidarium and laconicum. The rectangular pool is most likely the frigidarium (Fig. 6). In line with what has already been published (Marletta, 2010), the surveys we conducted allowed us to identify four main stratigraphic units (SU) on the surviving walls, which confirm the functions of the various rooms of the site and the different construction phases (Fig. 7)

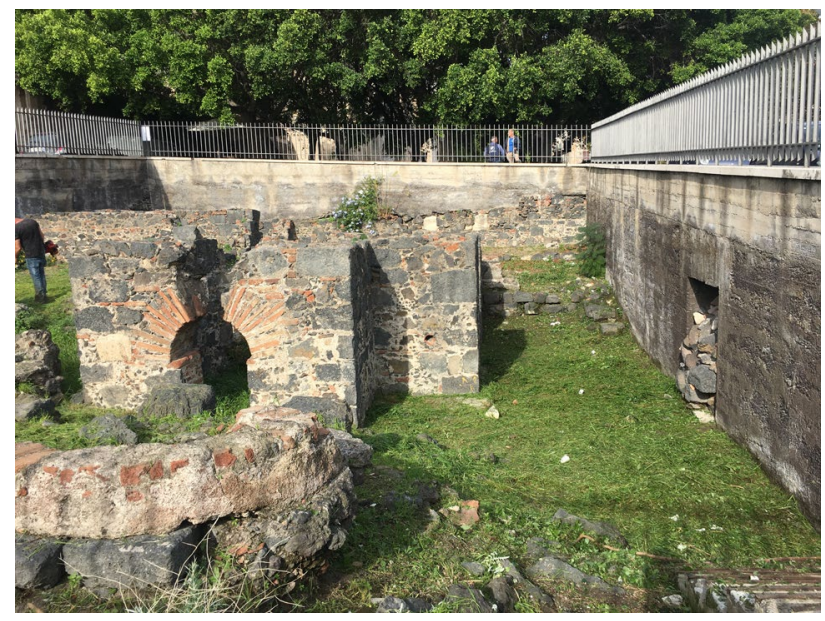

Figure 4. The Balneum within the excavation.

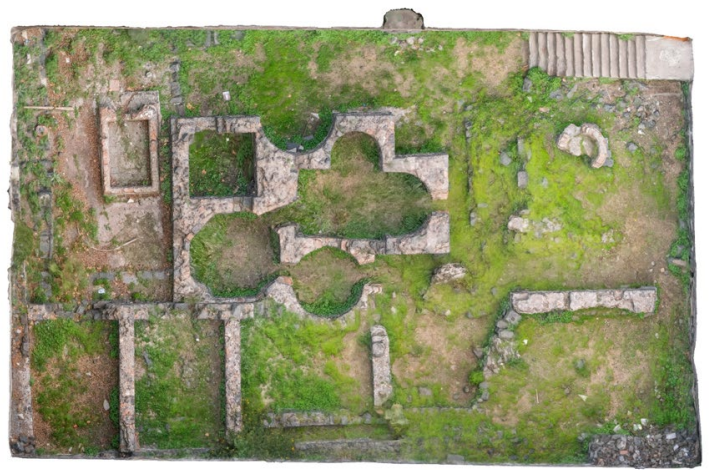

Figure 5. Top view of the 3D model.

The first SU corresponds to a wall panel that separated the Domus from the external space and the bath structure (in the area that once constituted the peristyle). In analogy to local building techniques of the imperial age, this masonry is made of almost square lava blocks (opus quadratum) and brick flakes, which contain a conglomerate core (opus caementicium). The second SU corresponds to the walls of the baths and is made of irregular lava stones, brick flakes and much mortar; this construction technique recalls that of the nearby "Terme dell'Indirizzo", confirming the hypothesis of a late imperial date. The Domus masonry (third SU) is made of shapeless basalt blocks of various sizes; this masonry is well organised with coarse horizontal load distribution joints. It is reinforced at the joints with lava and brick fragments and mortar. The fourth SU consists of the drystone completion walls built during the excavations of 1982 (Marletta, 2010). The different phases of construction of the Domus are also identified by the absence of interlocking stones between some orthogonal walls (Marletta, 2010). Fictile elements (hollow and circular section with a diameter of $40 \mathrm{~cm}$ ) formed the columns of the peristyle; the archivolts of the openings that connected the hypocaust with the thermal rooms are made of bricks alternating with lava flakes and mortar. Non-Destructive testing on the materials would certainly be decisive for dating and answering many hypotheses that are still totally conjectural.

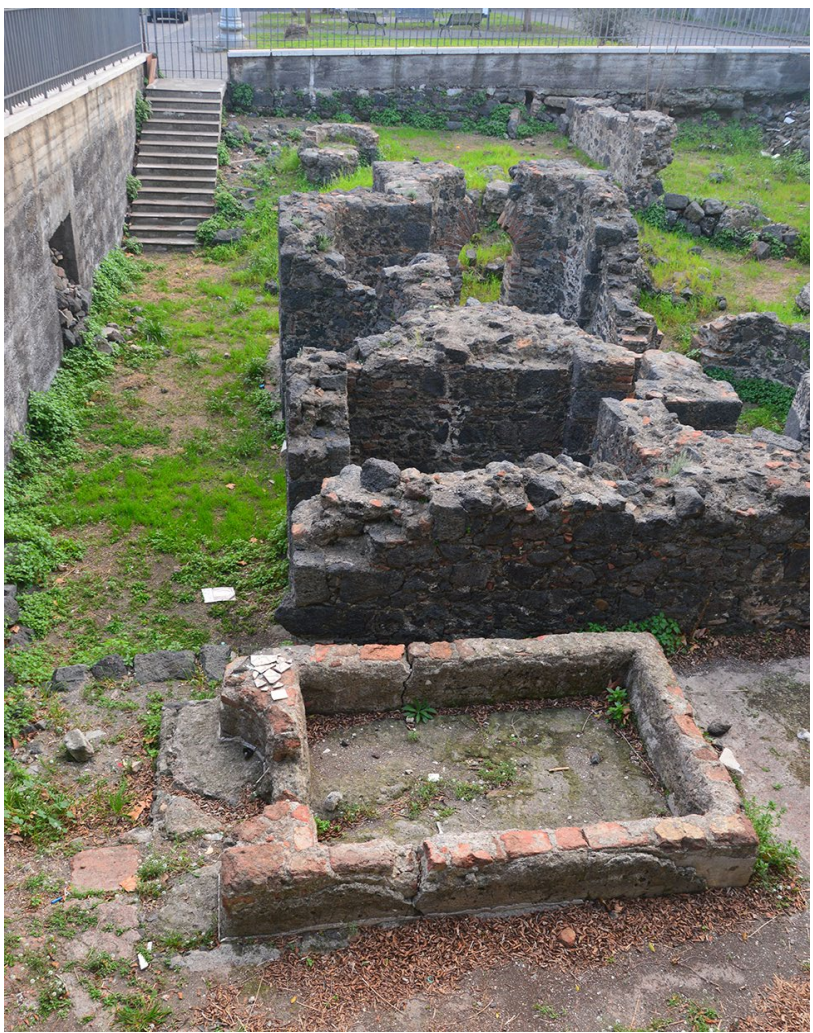

Figure 6. The Balneum: in the foreground the frigidarium, in the background the tepidarium and the calidarium.

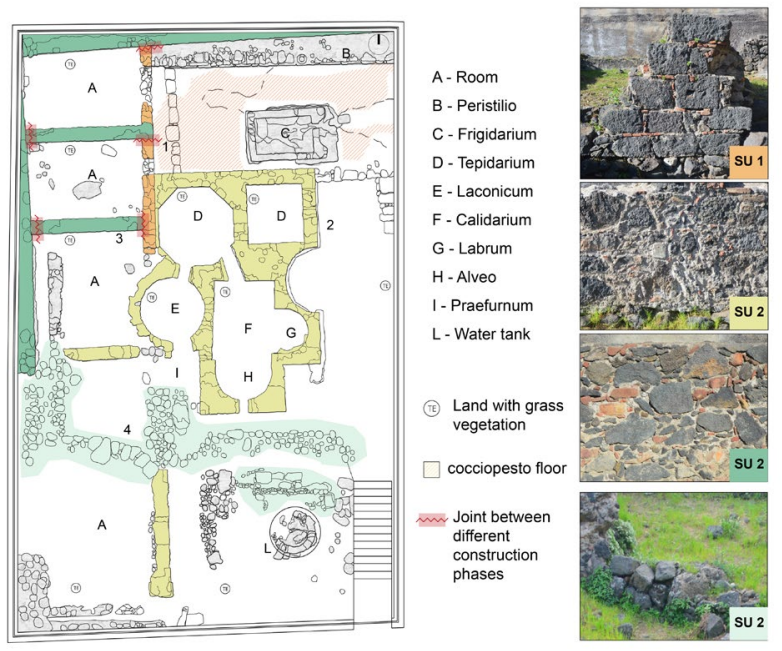

Figure 7. Localization of the Domus and Balneum rooms, SU mapping. Re-elaborations from 3D model and Marletta, 2010. 


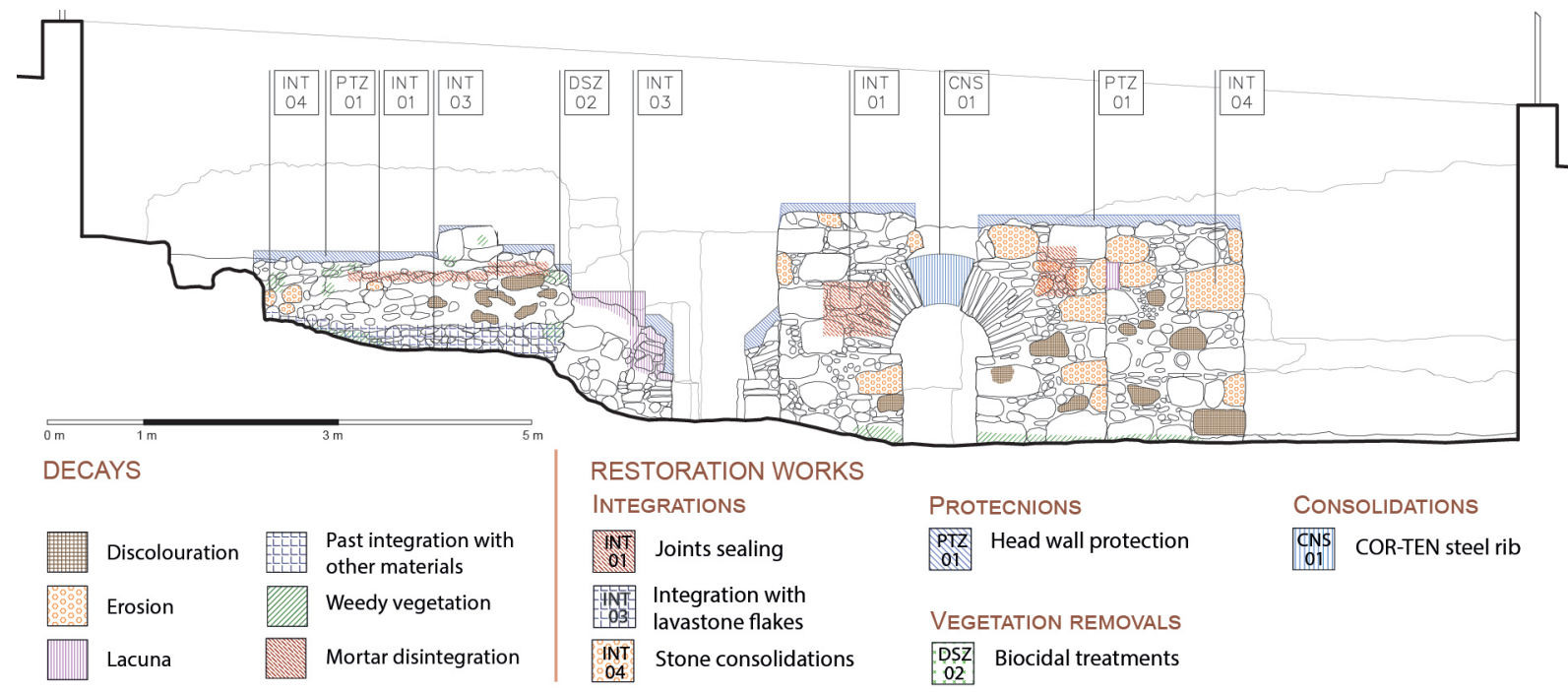

Figure 8. Decay analysis and conservation design.

\subsection{State of conservation}

In order to evaluate the overall conservation state, we have mapped on the photogrammetric model the visible signs of deterioration. This digital information makes it possible to monitor the degenerative state over time, creating accurate "dynamic surveys" (Marino, 2019). These surveys have shown us the most widespread decays, almost all of which are related to physical and biological phenomena or the natural wearing effect of time (Tab. 2). Erosion, the disintegration of mortar and wild vegetation are attributable to rainwater, as in many other cases of open-air sites. The ruins, in this case, have no cover or protection for water coming from the ground. However, although they are in contact with the ground, there is no trace of rising damp. Lacunas, loss of horizontality or verticality, and conspicuous missing portions of the walls can be traced back to neglect or past excavation works that paid little attention to preserving the ruins (Fig. 8).

\begin{tabular}{|c|c|c|}
\hline INSTABILITIES & DAMP & "FACIES"ALTERATIONS \\
\hline & \multicolumn{3}{|c|}{ Degradation visible signs } \\
\hline Lacuna & $\begin{array}{c}\text { Lacuna } \\
\text { Weedy vegetation } \\
\text { Eall inclination } \\
\end{array}$ & Lacuna \\
& $\begin{array}{c}\text { Mortar } \\
\text { disintegration }\end{array}$ & Weedy vegetation \\
\hline \multicolumn{3}{|c|}{ Degradation causes } \\
\hline $\begin{array}{c}\text { Unusual load } \\
\text { distribution } \\
\text { Root systems }\end{array}$ & $\begin{array}{c}\text { Stormwater } \\
\text { infiltration }\end{array}$ & Past excavations \\
\hline
\end{tabular}

Table 2. Macro-categories of decay in the Balneum.

\section{RESULTS}

\subsection{Restoration criteria: structural restoration and material conservation}

From identifying the signs of degradation, read directly on-site and measured on the digital replica, we arrived at the practical choices for both the restoration and the consolidation of the archaeological walls (Fig. 8).

The project plans to fill gaps and lacunae with plastering, as well as with the integration of new functional elements that also serve as anti-seismic protection; for example, the keystone ashlar of an arch and a Cor-Ten steel rib could consistently satisfy the requirements of recognisability, compatibility and reversibility, essential in the restoration project. The formal result and the technical functioning of these structural devices were verified on the digital replica. The material chosen is compatible with aesthetic and functional aspects (Fig. 9).

In other cases, we propose integrations and restorations with materials similar to the existing ones, respecting the local rule of art of the imperial age. Thus, we propose to protect the wall surfaces of the ruins from the physical and biological phenomena related to meteoric water (the main threat in openair sites without roofing) (Marino, 2019; Agostiano and Pane, 2013) by joints sealing and protecting the head of the walls with brick elements or layers of "cocciopesto" mortar and lava flakes. The dry-stone walls placed to fill in discontinuities of excavation in previous restorations could be replaced with walls of small lava ashlars. Finally, we believe that it is fundamental to study how to isolate the base of the walls with a new permeable footing, arranged to govern the meteoric waters with slopes and connections. All interventions, including cleaning treatments, should only be carried out after an accurate multidisciplinary diagnostic process.

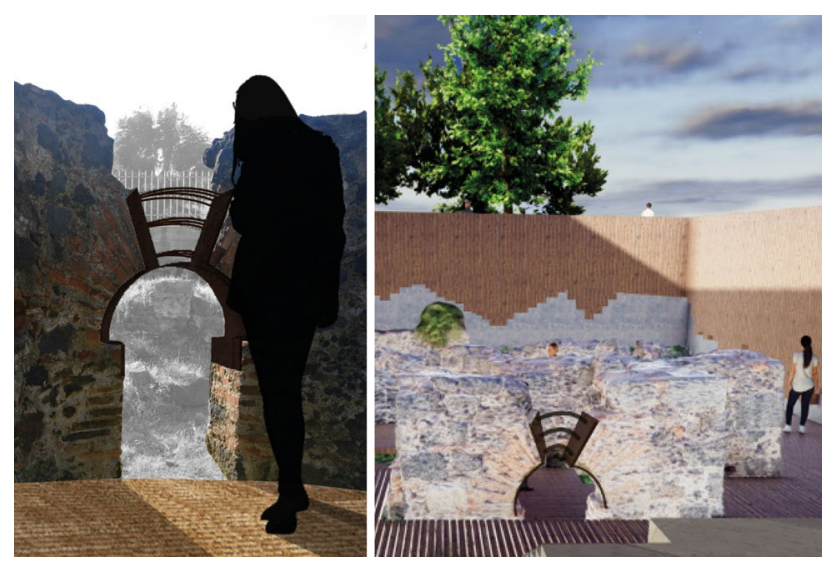

Figure 9. The proposed Cor-Ten steel rib: rendering view

(La Rosa, 2020).

\subsection{Preservation and enhancement strategies}

The site suffers mainly from decay caused by the lack of continuous maintenance. It is inside a trench inaccessible to the 
public (Fig. 10). The ruin appears as an inaccessible system of "silent" masonry panels, which form several geometric figures vaguely perceptible as thermal spaces (Fig. 11-12).

The site needs an enhancement design to improve visual perception and physical enjoyment. For this reason, we have thought of a system of steel footbridges at the height of the ancient walking surface, connected to the urban context by slight modifications to the road surface. New paths would lead right into the ruins, creating a direct relationship with the city (Fig. 13).

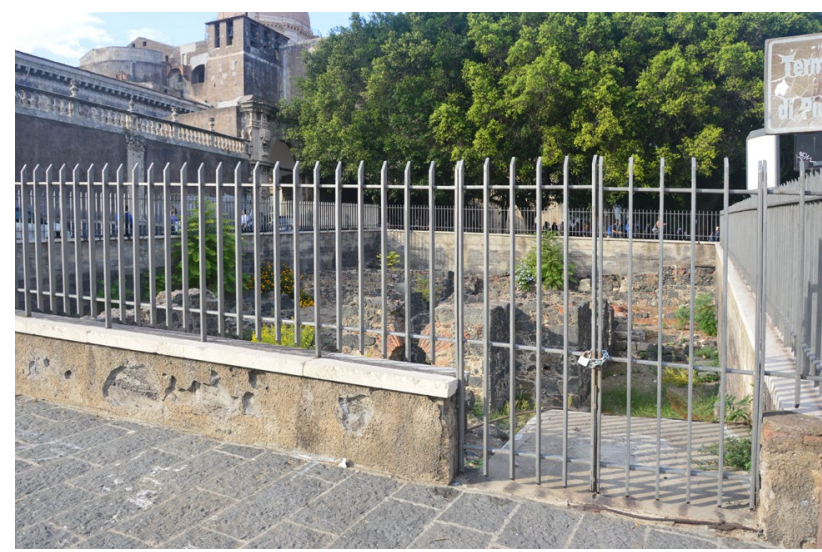

Figure 10. The inaccessibility of the archaeological trench in Piazza Dante.

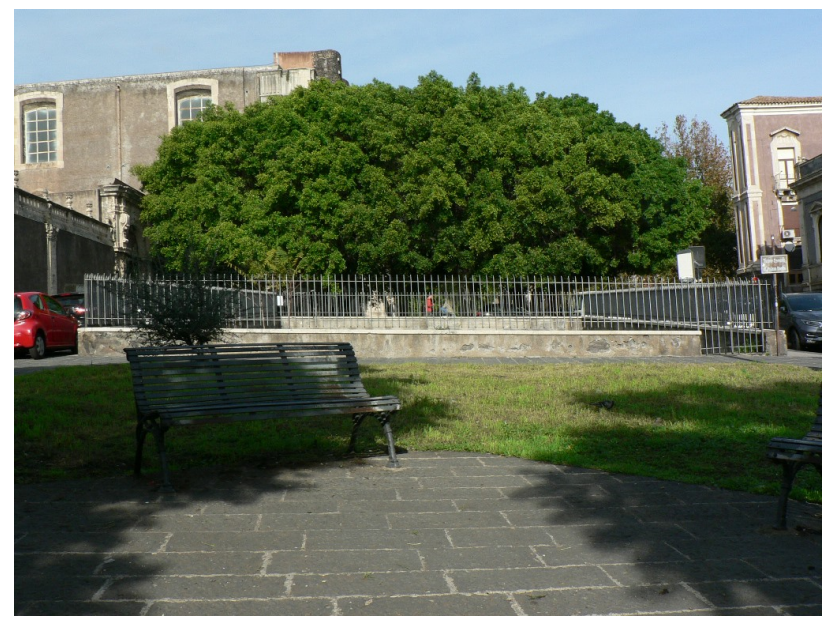

Figure 11. The enclosure of the Balneum.

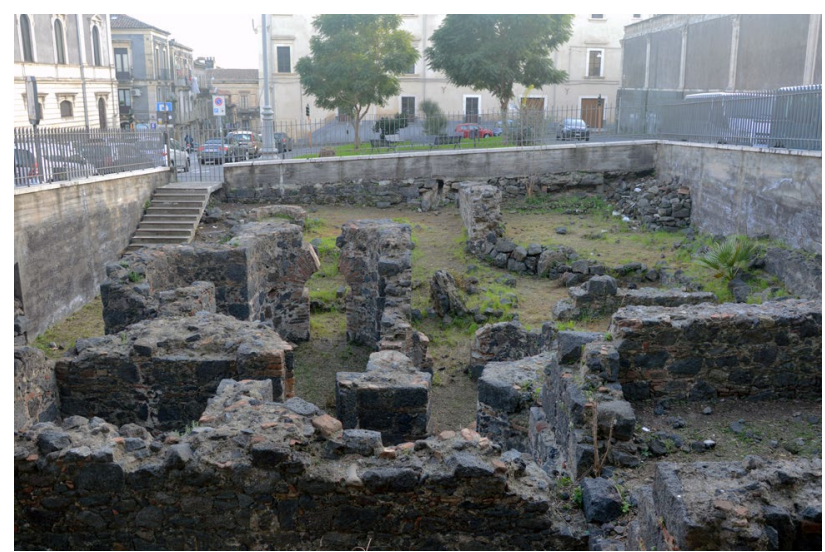

Figure 12. The Balneum in the current urban context.
The community would thus benefit from a new cultural space to be used daily, even by people with disabilities (Sanfilippo et al., 2021).

The reading of the architectural features of the site (improved by technical, formal and structural measures) would also be amplified through specific explanatory panels placed along the footbridges. The panels could also contain a Qr code to connect the user's mobile device to a digital network for all scientific and historical information.

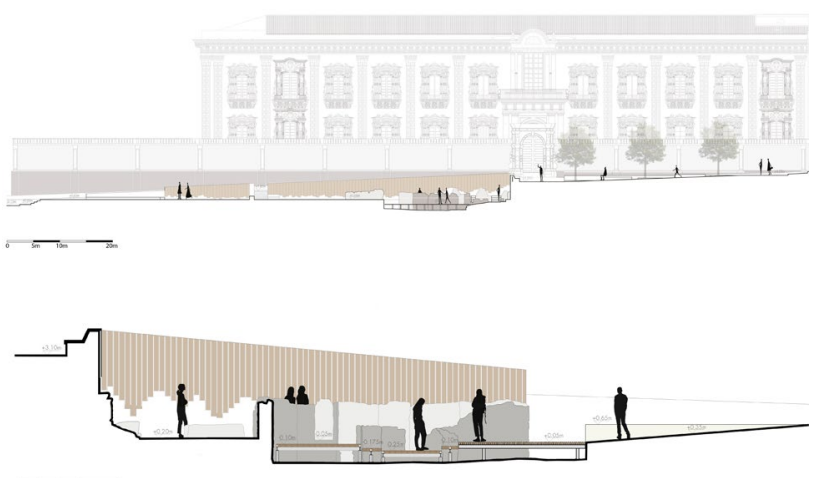

Figure 13. Design proposal for the site enhancement (Sanfilippo et al., 2021).

\subsection{The digital replica as an opportunity for the site valorisation and the monitoring of decay}

At this final stage, the entire collaboration team was able to enrich the model with the information (images, descriptions, data, etc.) produced during the analysis phase. Sketchfab's 3D annotations allow to apply "tags" directly to the surface of the mesh. Therefore, we identified points relevant to the analysis produced. Next, a thumbnail preview of the document was inserted with a brief description of its content and a link to access the document. Regarding the case study, the documents were stored in a Google Drive folder (Fig. 14).

The information in the cloud has been divided into several categories, following the methodological process that led us to the restoration design. Thus, we have included information about the site history and the archaeological studies about the Balneum and its Domus. The information also deals with the various excavations and past restorations. For this reason, we have also included a list of the existing bibliography on the topic. We have applied tags about the stratigraphic units' identifications, their technical qualities, and the different construction phases. Moreover, we have also linked the maps of the identified decays. These data are instrumental in starting monitoring over time, comparing the current state of conservation with the future one, and verifying the restoration project results.

Changes to the model are only allowed to those with credentials. In this way, the model can be updated, modified or reloaded over time by the designated team members who do not have to possess advanced computer skills to maintain the digital replica. However, the model can already be shared with the Sketchfab user community (200 million visitors in 2018) (Denoyel, 2018), who can view, explore and analyse the content. In addition, the uploaded model is easily embedded within other websites and social media. his feature can be really useful for dissemination activities intended to engage with 
different population segments, and it allows the digital model to be experienced on smartphones too. The sharing of information about the archaeological site and the consequent dissemination would allow better known a "minor" site of the Archaeological Park. It is because the knowledge of the asset is the necessary prerequisite for the preservation. "Opening" the site to the community, both physically and virtually through digital dissemination, could revive the sense of belonging to the place and facilitate the protection process.
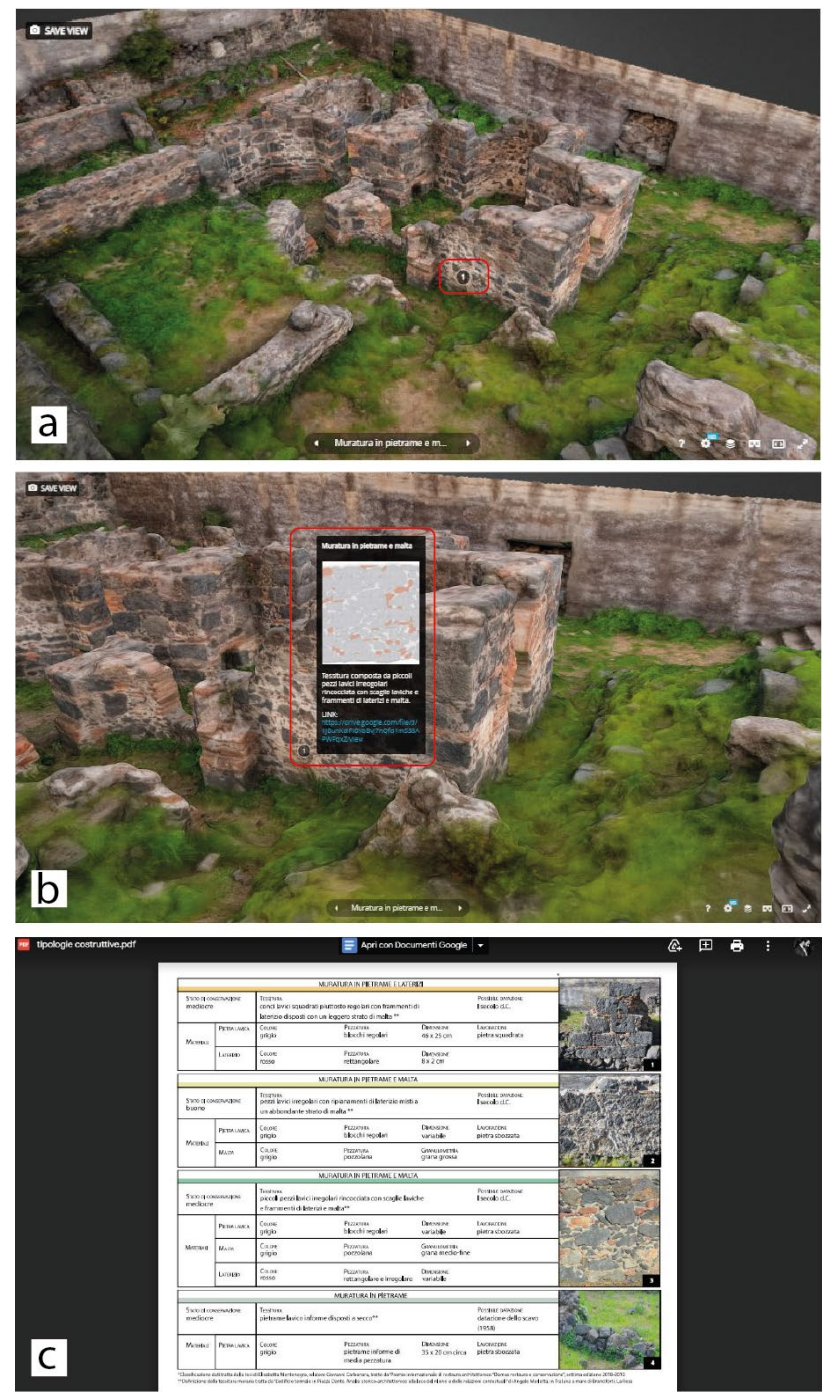

Figure 14. The 3D model in the Sketchfab platform: a) exploring; b) interacting with tags; c) consulting documentation.

\section{CONCLUSIONS}

We were able to develop interactive documentation, useful not only for the analysis phases but also for better communication of the site restoration plan and virtual enhancement.

The accessibility of the proposed workflow (based on low-cost technologies) facilitates the planning of constant monitoring actions on the site. Thus, we create a workflow around the digital replica of the archaeological site directly from the photogrammetric model, avoiding additional time and resources about the reverse engineering of the site (especially reference to HBIM methodologies). The model reflects the principles of "digital replica". Applying these principles in a "program for the planned conservation' is a significant opportunity, as already demonstrated by state-of-the-art HBIM applications. Simplifying the process by interacting directly with digital survey products, where possible, would require less energy and expertise. This would allow information enrichment to be carried out directly on the mesh model. Furthermore, as demonstrated in the case study, the rapid time of photo acquisition and mesh processing (less than one hour and twenty minutes) allows the sustainability of the monitoring activity that could be consulted through the development of time-line machines directly on the mesh. In this way, it would be possible to dynamically map the evolution of deterioration on the site over time.

The resulting mesh model can be easily consulted by professionals with no digital experience thanks to the visualisation tools that current 3D web portals allow. The Sketchfab portal allows an easy and direct exchange between all researchers, professions and students involved in the site study. Moreover, the millions of users already active within the online platform represent a very high potential for dissemination purposes. If networked with other models of the nearby archaeological sites, this model could be a relevant tool for enhancing the heritage in the Archaeological and Landscape Park of Catania and the Aci Valley.

\section{ACKNOWLEDGEMENTS}

This research was funded by "Piano di incentivi per la ricerca di Ateneo 2020/2022 (Pia.ce.ri.)" of University of Catania.

The authors would like to thank Dr G. Lamagna and Dr F. Nicoletti of the Archaeological and Landscape Park of Catania and the Aci Valley for their support.

The research was carried out within a multidisciplinary collaboration, but due to the specificity of the topics covered: G.S. edited sections 3, 4.1, 4.3, 4.4, 5.1; A.M. edited sections 2.1, 3, 5.2, 5.3; F.M.LR. edited sections 2.2, 3, 4.2, 5.3. All authors edited sections 1 and 6. L.LR. also collaborated on the paper graphic design.

\section{REFERENCES}

Acierno, M., 2020. La rappresentazione integrata della conoscenza come strumento di tutela e restauro della scala urbana: riflessi e conseguenze di un cambiamento di approccio metodologico. In D. Fiorani, E. Romeo (Eds.), Restauro, Conoscenza, Progetto, Cantiere, Gestione. Sezione 4.1. Realizzazione degli interventi Gestione, valorizzazione, prevenzione. Edizioni Quasar, Roma, 559-568.

Agostiano, M., Pane, A., 2013. Indirizzi operativi per una fruizione ampliata del sito archeologico di Pompei. In R. Picone (Ed.) Pompei accessibile. Per una fruizione ampliata del sito archeologico. L'Erma di Bretschneider, Roma, 445-458.

Barrettara, M., 2013. New methods for sharing and exhibiting 3D archaeology. The Posthole, 31, 8-13.

Bartolomucci, C., Trizio, I., 2015. Dal rilievo del danno sismico al disegno per il progetto di restauro: un'applicazione di documentazione speditiva in condizioni di emergenza. Disegnare Con, 8 (14), 24.1-24.8.

Branciforti, M.G., 2010. Da Katáne a Catina. In M.G. Branciforti, V. La Rosa (Eds.), Tra lava e mare. Contributi all'archeologia di Catania, Le nove muse editrice, Catania, 135-258. 
Champion, E., Rahaman, H., 2020. Survey of 3D digital heritage repositories and platforms. Virtual Archaeology Review, 11(23), 1-15. doi.org/10.4995/var.2020.13226

Dal Mas, R., M., 2017. L'apporto delle nuove tecnologie di rilievo nel restauro. In D. Fiorani and A. Grimoldi (Eds.), RICerca/REStauro, Sezione 2A: Conoscenza dell'edificio: metodo e contenuti. Edizioni Quasar, Roma, 459-468.

D’Agostino, G., Galizia, M., Mangiameli, M., Mussumeci, G., Portale, E. C., Santagati, C., Tigano, G., Torre, R., 2018. Rilievo integrato per la conoscenza e documentazione del complesso termale dell'area archeologica di Tindari (ME). In F. Minutoli, (Ed.), ReUSO 2018 L'intreccio dei saperi per rispettare il passato interpretare il presente salvaguardare il futuro. Gangemi Editore, Roma, 365-376.

Demetrescu, E., D'Annibale E., Ferdani D., Fanini, B., 2020. Digital replica of cultural landscapes: An experimental realitybased workflow to create realistic, interactive open world experiences. Journal of Cultural Heritage, 41, 125-141. doi.org/10.1016/j.culher.2019.07.018

Denoyel, A., 2018. 2 million users, 200 million visitors and 1 billion page views. Sketchfab Community Blog. https://sketchfab.com/blogs/community/2-million-users-200million-visitors-and-1-billion-page-views/ (20 June 2021)

Denoyel, A., 2020. Sketchfab for Teams. Sketchfab Community Blog. https://sketchfab.com/blogs/community/announcingsketchfab-for-teams/ (20 June 2021)

Fiorani, D., Balletti, C., 2017. Repliche digitali e fisiche - realtà aumentata, restauro virtuale. Due prospettive d'indagine. In G. Tucci, E. I. Parisi (Eds.), ANANKE ('ANATKH) - Speciale GEORES2017, Altralinea, Firenze, 16-17.

Giudice, F., Procelli, E., Albanese R.M., Frasca, M., 1979. Catania. Scavo all'interno del muro di cinta del Monastero dei Benedettini. CronCat, 18, 129-141.

Guidi, G., Micoli, L.L., Gonizzi, S., Navarro, P.R., Russo, M., 2013. 3D digitizing a whole museum: a metadata centered workflow. In 2013 Digital Heritage International Congress (DigitalHeritage2013), Institute of Electrical and Electronics Engineers (IEEE), 307-310. doi.org/10.1109/DigitalHeritage.2013.6744768

Iaccarino Idelson, A., Pannuzi, S., Brunetto, A., Galanti, G., Giovannone, C., Massa, V., Serino, C., and Vischetti, F., 2017. Use of $3 \mathrm{D}$ technologies within the conservation of the ancient windows of the Basilica of S. Sabina in Rome. Construction of exhibition stands in carbon composite on a milled structure. Int. Arch. Photogramm. Remote Sens. Spatial Inf. Sci., XLII-5/W1, 593-598. doi.org/10.5194/isprs-archives-XLII-5-W1-593-2017, 2017.

La Rosa, L., 2020. Valorizzazione e accessibilità dei siti archeologici urbani. un progetto per il Balneum in piazza Dante a Catania. Master's Thesis in Building Construction and Architectural Engineering, University of Catania.

Marino, L., 2019. Il restauro dei siti archeologici e manufatti edili allo stato di rudere, DidaPress, Firenze.

Marletta, A., 2010. L'edificio termale in Piazza Dante. Analisi storico-architettonica alla luce del rilievo e delle relazioni contestuali. In M.G. Branciforti, V. La Rosa (Eds.), Tra lava e mare. Contributi all'archeologia di Catania, Le nove muse editrice, Catania, 259-288.

Pagnano, G., 2007. La costruzione dell'identità di Catania dal secolo XVI al XX. In M. Ayrmard, G. Giarrizzo (Eds.), Catania. La città, la sua storia, Domenico Sanfilippo Editore, Catania, 181-237

Pamart, A., Morlet, F., De Luca, L., 2019. A fully automated incremental photogrammetric processing dedicated for collaborative remote-computing workflow. Int. Arch. Photogramm. Remote Sens. Spatial Inf. Sci. XLII-2/W9. 565571. doi.org/10.5194/isprs-archives-XLII-2-W9-565-2019

Pollalis, C., Minor, E. J., Westendorf, L., Fahnbulleh, W., Virgilio, I., Kun, A. L., Shaer, O., 2018. Evaluating Learning with Tangible and Virtual Representations of Archaeological Artifacts. In Proceedings of the XX International Conference on Tangible, Embedded, and Embodied Interaction (TEI '18). Association for Computing Machinery, New York, NY, USA, 626-637. doi.org/10.1145/3173225.3173260

Quattrini, R., Gasparetto, F., Angeloni, R., D’Alessio, M., 2019. Modelli digitali per comunicare il patrimonio e l'intervento di restauro. Palazzetto Baviera di Senigallia. Archeomatica, 10 (3), 24-27. doi.org/10.48258/arc.v10i3.1683

Romeo, E., 2014. Valorizzazione dei siti archeologici tra conservazione della memoria storica, nuovi linguaggi e nuove tecnologie. In E. Romeo, E. Morezzi, R. Rudiero, Riflessioni sulla conservazione del patrimonio archeologico. ARACNE Editrice srl, Roma, p. 15-90.

Sanfilippo, G., Aquilia, E., D’Agostino, G., 2015. Scientific and interdisciplinary method as support for the restoration project. The balustrade steps of Villa Cerami. SCIRES-IT: SCIentific RESearch and Information Technology, 5, 77-92. doi.org/10.2423/i22394303v5n1p77

Sanfilippo, G., Mondello, A., La Rosa, L., 2021. Accessibilità e fruizione dei siti archeologici nel centro storico di Catania. Stato dell'arte e progetti. In M.L. Germanà, R. Prescia (Eds.), L'accessibilità nel patrimonio architettonico. Approcci ed esperienze tra tecnologia e restauro. Anteferma Edizioni, Conegliano, 82-91.

Valle Melón, J.M., Pérez Vidiella, P., Rodríguez Miranda, A., D’Anna C.M., Uceda Queirós, S., 2016. El modelo 3D como base para la documentación y difusión de los elementos patrimoniales. Aplicación al mausoleo romano denominado 'la Sinagoga' de Sádaba (Zaragoza, España). Restauro Archeologico, 24 (1), 4-19.

Wilson, R.J.A., 1990. Sicily under the Roman Empire. The archaeology of a Roman province, $36 B C-A D$ 535, Aris and Phillips, Warminster. 